\title{
Policy programme cycles through old and new programmatic groups
}

\author{
Nils C. Bandelow ${ }^{\star}(\mathbb{D})$ and Johanna Hornung (D) \\ Comparative Politics and Public Policy, TU Braunschweig, D-38106 Braunschweig, Germany \\ *Corresponding author. E-mail: nils.bandelow@tu-braunschweig.de
}

(Received 31 December 2018; revised 15 June 2020; accepted 07 July 2020; first published online 11 August 2020)

\begin{abstract}
This article draws on the Programmatic Action Framework (PAF) to tackle the question of how the dominance and decline of a specific policy programme in a policy sector can be explained. It starts from the observation that visionary policy programmes, defined as a set of policy goals and instruments that find their expression in subsequently adopted and interconnected policy reforms, may shape a sector's policies over several decades. Linking policy programmes to programmatic groups that promote these programmes in search of boosting their careers and authority, the programme's rising and declining dominance can be explained by the career trajectories of programmatic actors. By displaying empirical evidence for the argument from German health policy, the article shows that proponents of today's change are opponents of tomorrow's change since individual careers depend on the dominance of policy programmes.
\end{abstract}

Key words: health policy; policy change; policy stability; Programmatic Action Framework (PAF); programmatic dominance; social groups

\section{Introduction}

The Programmatic Action Framework (PAF) introduced programmatic groups and their policy programmes into policy process research (Bandelow et al., 2020; Hassenteufel and Genieys 2020). Programmatic groups are defined as social groups of individuals within the state that form on the basis of shared biographic experiences and create a social group identity by committing to a policy programme. Policy programmes are defined as sets of policy goals and related instruments based on an inherent problem perception and resulting structural solutions that, for several decades, may shape a sector's policies (Nyby et al. 2018). More specifically, $\mathrm{PAF}$ postulates that the career aspirations of actors who are directly involved in the

The authors thank the reviewers and editors for their valuable comments and Ilana Schröder for her amazing help in answering them.

(C) The Author(s), 2020. Published by Cambridge University Press. This is an Open Access article, distributed under the terms of the Creative Commons Attribution-NonCommercial-NoDerivatives licence (http://creativecommons.org/ licenses/by-nc-nd/4.0/), which permits non-commercial re-use, distribution, and reproduction in any medium, provided the original work is unaltered and is properly cited. The written permission of Cambridge University Press must be obtained for commercial re-use or in order to create a derivative work. 
policy-making process can matter in the promotion and persistence of policy programmes, based on the premise that policy actors strive to enhance authority and expect occupational benefits and normative returns from pursuing policy ideas (Dolan 2000). Previous applications of the PAF and evidence for its hypotheses concern health policy (Genieys and Smyrl 2008), labour market policy (Bandelow and Hornung 2019) and defence policy (Faure 2020).

While the PAF explanation for policy change rests on programmatic groups that pursue a joint policy programme out of career-related and normative reasons, it has so far not explicitly addressed the question of how long-term dominance of a policy programme (policy stability) and its eventual decline can be explained. Applying the $\mathrm{PAF}$, we argue that the hypothesis of programmatic groups promoting programmes to advance their careers suggests that the variations in programmes closely tracks proponents' career trajectory. PAF may thereby answer the question of how programmatic dominance, despite usually change-inducing developments, can be explained and what PAF adds to the understanding of the rise and decline of policy programmes. Against the backdrop of the hypotheses that programmatic groups and policy programmes institutionalize themselves out of strategic career interests and that greater inclusiveness of the programmatic group and its programme leads to long-term programmatic dominance, the PAF presents an endogenous explanation for policy stability.

The role of actors - or agency - and especially their careers and biographies in long-term phases of policy change and stability is yet undertheorized (May and Jochim 2013, 446). While the established perspectives inherently capture a dynamic of alternating phases of policy stability and change over time (Capano and Howlett 2009), the foci of interests differ. Perspectives on policy stability identify stabilizing determinants of path dependence and preshaped trajectories for incremental change through feedback effects as well as critical junctures at which departing from this path would lead to major change (Koning 2016; Mettler and Sorelle 2017; Béland and Schlager 2019; Hogan 2019). However, they do not explicitly address a continuous major change in a certain programmatic direction. By contrast, theories of policy change shed light on how external perturbations (crises, societal developments and the like), policy actors (individual or collective) and learning affect major policy change (Zafonte and Sabatier 1998; Herweg et al. 2017; Weible and Sabatier 2017). So far, these neglect the importance of shared biographical and career-related trajectories and interests in explaining the rise and decline of policy programmes.

The upcoming section reviews existing theories of policy change and stability to emphasize the peculiarities of the PAF perspective with a focus on its contribution to understanding cyclical patterns of programmatic dominance. Based on this, the third section conceptualizes programmatic groups and policy programmes in order to substantiate testable hypotheses on the interrelation of programme characteristics, actor characteristics and programmatic dominance. The case study of German health policy from 1992 to 2011 constitutes an empirical anchor for the argument that the rise and decline of a policy programme followed a pattern of economic cycles. A final conclusion summarizes avenues for future research and discusses the scope and limitations of PAF. 


\section{Policy process theories of change and stability}

Structuralist perspectives on the policy process generally have a larger focus on institutions blocking major change instead of investigating the factors that actively bring about change, such as actor networks. Regarding stability, prominent literature on path dependency has taught us that, in specific situations, altering existing structures is as costly as time-consuming and thus policy-makers stick to the status quo (Wilsford 1994; Mahoney 2001; Thelen 2003) or that policy-making takes place incrementally in its regular venues, with the usual types of actors involved, and a dominant policy image shaping actors' perceptions of problems and appropriate solutions, termed as "negative feedback" (Baumgartner et al. 2009; Baumgartner et al. 2017). Previous policies thereby shape trajectories for subsequent policy decisions, which are known under the term "policy feedback." Actors can challenge and depart from these trajectories, though (Béland 2010, 575). Tying in with this discussion, the PAF focuses on long-term persistence and institutionalization of a policy programme and theoretically links it to actor groups.

Turning to the factors that interrupt the stability and enable major policy change in structuralist and institutionalist theories, policy termination literature takes into account institutional opportunities and constraints for the dismantling of policies and refers to external influences like permanent austerity or crises in creating the desire for policy dismantling (deLeon 2007; Jordan et al. 2013; Pollex and Lenschow 2019). Bauer and Knill (2014) assume that policy actors act rationally according to cost-benefit analyses and particularly the goal of electoral success when dismantling and terminating policies. Additionally, the notion of critical junctures refers to the identification of instances when there is a chance for policy termination and major policy change beyond incremental change (Hogan 2019; Rinscheid et al. 2019). In accounting for both exogenous and endogenous triggers for critical junctures, incrementalists have centred on the concept of actors inherent particularly in ideational institutionalism to assess in what way and under what circumstances actors alter institutions and policies (Koning 2016). Then, change is often ascribed to different factors such as policy networks resolving policy failures (Coleman et al. 1996) or narratives of crisis impacts that prompt a new, fitting policy paradigm (Oliver and Pemberton 2004; Kern et al. 2014). In the view of Hacker and Pierson (2014), actor groups strategically act in the policy process to fight for authority and, when succeeding in this struggle, are rewarded with the ability to shape governance and policies. In policy regime perspectives, regime durability then follows from changes in the composition of political power and interests, declining support among the coalition that braces the regime or certain partisan coalitions that benefit from maintaining support for a policy regime (Jochim and May 2010, 320).

Actor-centred perspectives on policy change and stability bring in different lenses on the linkage between actors and ideas. A first look is devoted to policy communities, policy networks, issue networks and epistemic communities. While policy networks encompass different types of networks that are characterized by different degrees of close and coordinated cooperation and different scopes of actor inclusion (Döhler 1991; Jordan and Schubert 1992), policy communities, issue networks and epistemic communities each present a specific type of network, distinguished by 
Table 1. Explanation and distinction of subject-specific terms

\begin{tabular}{|c|c|}
\hline Term & Explanation \\
\hline Programmatic groups & $\begin{array}{l}\text { Social groups of individuals within the state apparatus that form on the } \\
\text { basis of shared biographic experiences and create a social group } \\
\text { identity by committing to a policy programme. }\end{array}$ \\
\hline Programmatic identity & $\begin{array}{l}\text { Identification with a programmatic group due to the feeling of belonging, } \\
\text { positive assessment and emotional attachment. }\end{array}$ \\
\hline Policy subsystem & $\begin{array}{l}\text { Defined "as the set of actors who are involved in dealing with a policy } \\
\text { problem" (Sabatier and Jenkins-Smith } 1993,24) .\end{array}$ \\
\hline Issue network & $\begin{array}{l}\text { Specific types of networks with a large number of actors, varieties of } \\
\text { interests, resources and power positions (Marsh and Rhodes 1992). }\end{array}$ \\
\hline Epistemic communities & $\begin{array}{l}\text { "Networks of knowledge-based experts" that propose policies, assist states } \\
\text { in decision-making processes and help them in formulating and } \\
\text { identifying issues (Haas 1992, 2). }\end{array}$ \\
\hline Policy regime & $\begin{array}{l}\text { Governing arrangements consisting of the intersection of multiple policy } \\
\text { subsystems (Jochim and May 2010, 308). The perspective of policy } \\
\text { regimes examines to what extent public policies define "feedback } \\
\text { processes that reshape the political environment" (May and Jochim } \\
2013,427 \text { ). }\end{array}$ \\
\hline Policy paradigm & $\begin{array}{l}\text { A perspective on problems and solutions, which spans a subsystem. It } \\
\text { predefines stances and answers all questions of a subsystem (Hall } \\
\text { 1993). }\end{array}$ \\
\hline Policy programme & $\begin{array}{l}\text { Set of policy goals and related instruments based on an inherent problem } \\
\text { perception regarding the definition of problems and the articulation of } \\
\text { solutions (Genieys and Hassenteufel 2015, 282) that shape a sector's } \\
\text { policies. Policy programmes are always connected to programmatic } \\
\text { groups and can be as broad as subsystem spanning but can also be } \\
\text { limited to a certain, very specific policy idea. }\end{array}$ \\
\hline
\end{tabular}

the number of actors, homogeneity, variety of interests, agreement on policy goals, transnationality, sector specificity, resources and power positions (Marsh and Rhodes 1992; Dunlop 2009; Mavrot and Sager 2018; Elander and Gustavsson 2019). Yet these types of networks are rarely bound to a subsystem and therefore can hardly promote a sectoral policy programme that, over a longer period of time, dominates sectoral policy. Moreover, they neither include shared biographies, nor a career interest in the group's members. The differences between programmatic groups and other network types are detailed in Table 1.

Why do actors promote certain content? The Advocacy Coalition Framework (ACF) sees shared beliefs as the driving factor of cooperation (Sabatier and Jenkins-Smith 1993; Weible and Ingold 2018). However, ACF studies suggest that trust and resources are sometimes more and sometimes less important for cooperation than shared beliefs (Matti and Sandström 2011; Calanni et al. 2014; Fischer et al. 2016; Weible et al. 2018). The Multiple Streams Framework (MSF) (Herweg et al. 2017; Sager and Thomann 2017) primarily refers to situational explanations for explaining change; stability here just results from the absence of policy windows and/or adequate strategies of entrepreneurs. Moreover, a policy entrepreneur pushing a policy proposal out of strategic self-interest does so in an ambiguous environment that does not actively promote her/his pet policy but grants it (Zahariadis 2014; Herweg et al. 2015; Béland and Howlett 2016).

Summarizing this section, what PAF adds to the presented theoretical lenses is a European perspective on policy change and stability that assumes biographical 
intersections and resulting trust as the root for collective action and a career-related promotion of policy programmes within a policy subsystem as an explanation for programmatic dominance. PAF's main focus lies on the long-term role of actors in key positions whose career is connected to the success of a policy programme. The PAF is thereby distinct from existing theoretical perspectives both with regard to the theoretical mechanisms linking actors and policy change and with regard to terminology and term definitions. These have been reviewed above and compiled in an overview presented in Tables 1 and 2.

\section{Programmatic groups and policy programme cycles}

PAF starts from the idea that policy programmes are associated with programmatic groups and that this view can explain long-term policy persistence because it enables a focus on programme- and actor-related characteristics that, in combination, explain policy programme persistence in its dynamic of alternating policy change and stability. It understands programmatic groups as composing actors with direct influence in the policy process and particularly on policy content who ally out of strategic reasons to push their individual careers and influence within the subsystem. A programmatic group adopts a policy programme that functions both as a binding element of the programmatic group and as a means of leverage to realize the common goal of increased authority. The term programmatic group denotes an irrevocable tie between a policy programme and a programmatic group that is committed to this programme. Such group membership then builds the basis for mutual trust and collaboration (Tanis and Postmes 2005; Stern and Coleman 2015). We build upon these factors that enable long-term stability of the policy programme and thus explain policy persistence over career cycles. The end of a policy program is determined by the observation that no programmatic actors of the policy program can be found in the identified key positions.

From this argument, one can derive the assumption that policy programmes follow a pattern of cycles. The mechanism behind this pattern is a logical array of developments within a policy subsystem. It proceeds from the basic assumptions that (1) in political systems, there are limited positions of power which are central in decision-making processes and that (2) actors in policy subsystems strive to maximize their influence and authority by occupying these positions. It can be hypothesized that there are different phases of a programmatic "cycle," which determine the likelihood of a policy programme's persistence. Figure 1 depicts this cyclical pattern that is accordingly formulated as the programme cycle hypothesis.

Phase I: The programmatic group forms and develops a joint policy programme. This policy programme is not a result of shared ideology, beliefs or other types of value-based preferences but rather serves as an instrument to enter the struggle over authority in the sector. Central to the programmatic group's motive is to make the policy programme succeed in order for the programmatic group to place itself in top-level positions that assert dominance within a policy subsystem. Phase I, the development phase, is a phase that is independent of other existent programmes in other phases and is always possible to run through by policy programmes and programmatic groups. The existence of other parallel programmes is possible but 
Table 2. Comparison of theoretical approaches in relation to the PAF

\begin{tabular}{|c|c|c|c|c|c|}
\hline Theory & PAF & ACF & MSF & PET & $\begin{array}{l}\text { Policy feedback/Historical } \\
\text { institutionalism }\end{array}$ \\
\hline Main focus & $\begin{array}{l}\text { Group theoretical perspective on } \\
\text { long-term policy-making, rise } \\
\text { and decline of policy } \\
\text { programmes. }\end{array}$ & $\begin{array}{l}\text { Coalition building, } \\
\text { policy change and } \\
\text { learning, }\end{array}$ & $\begin{array}{l}\text { Agenda setting, } \\
\text { defining of policy } \\
\text { alternatives and } \\
\text { decision-making } \\
\text { under the condition } \\
\text { of ambiguity. }\end{array}$ & $\begin{array}{l}\text { Instability of long-term } \\
\text { developments of policy } \\
\text { agenda setting. }\end{array}$ & $\begin{array}{l}\text { Shaping paths by previous policies } \\
\text { for following policy decisions and } \\
\text { an explanation for how political } \\
\text { actors are affected by previous } \\
\text { policy designs. }\end{array}$ \\
\hline Actors & $\begin{array}{l}\text { Individuals within the state } \\
\text { apparatus. }\end{array}$ & $\begin{array}{l}\text { Individuals (and } \\
\text { organizations) } \\
\text { that deal with a } \\
\text { policy problem. }\end{array}$ & $\begin{array}{l}\text { Decisions-makers and } \\
\text { policy } \\
\text { entrepreneurs. }\end{array}$ & $\begin{array}{l}\text { Policy individuals or } \\
\text { organizations (frictions } \\
\text { with subsystems to } \\
\text { process information). }\end{array}$ & $\begin{array}{l}\text { States, institutions, individual } \\
\text { political actors and organizations. }\end{array}$ \\
\hline $\begin{array}{l}\text { Characteristics } \\
\text { of actors }\end{array}$ & $\begin{array}{l}\text { Actors are connected by a } \\
\text { subjective social identity, } \\
\text { shared biographies and career } \\
\text { trajectories. Programmatic } \\
\text { actors/groups struggle for } \\
\text { career advancement, authority } \\
\text { and the implementation of a } \\
\text { policy programme. }\end{array}$ & $\begin{array}{l}\text { Actors have } \\
\text { hierarchical belief } \\
\text { systems. } \\
\text { Coalitions are } \\
\text { connected by } \\
\text { shared policy core } \\
\text { beliefs. }\end{array}$ & Actors are ambiguous. & $\begin{array}{l}\text { Actors with bounded } \\
\text { rationality use routine- } \\
\text { based problem-solving } \\
\text { techniques. }\end{array}$ & $\begin{array}{l}\text { Actors can depart from trajectories } \\
\text { shaped by past policies. However, } \\
\text { they consider this to be too } \\
\text { resource intensive to leave the } \\
\text { status quo and pursue new paths. }\end{array}$ \\
\hline $\begin{array}{l}\text { Reasons for } \\
\text { stability }\end{array}$ & $\begin{array}{l}\text { Exhaustion of dominant } \\
\text { programme, end of } \\
\text { programme cycle. }\end{array}$ & $\begin{array}{l}\text { Stable core beliefs, } \\
\text { absence of } \\
\text { external and } \\
\text { internal shocks } \\
\text { and stability of } \\
\text { resources. }\end{array}$ & $\begin{array}{l}\text { Lack of subjective } \\
\text { problem pressure, } \\
\text { lack of power } \\
\text { change and failure } \\
\text { of entrepreneur. }\end{array}$ & Negative feedback cycles. & $\begin{array}{l}\text { Maintaining the status quo of } \\
\text { previous policies. Orientation and } \\
\text { adaptation of existing institutions } \\
\text { and ideas. }\end{array}$ \\
\hline $\begin{array}{l}\text { Reasons for } \\
\text { change }\end{array}$ & $\begin{array}{l}\text { Emergence of a new dominant } \\
\text { programmatic group, } \\
\text { implementation of a } \\
\text { programme by dominant } \\
\text { programmatic group. }\end{array}$ & $\begin{array}{l}\text { External shocks, } \\
\text { internal shocks, } \\
\text { negotiated } \\
\text { agreements and } \\
\text { policy learning. }\end{array}$ & $\begin{array}{l}\text { Policy windows used } \\
\text { by entrepreneurs to } \\
\text { get their promoted } \\
\text { solutions. }\end{array}$ & $\begin{array}{l}\text { Positive feedback cycles } \\
\text { leading to the inclusion } \\
\text { of new actors and fields } \\
\text { of competence in the } \\
\text { decision-making } \\
\text { process. }\end{array}$ & $\begin{array}{l}\text { Actors' own interests and } \\
\text { competition between } \\
\text { organizations. Implementation of } \\
\text { new concepts, expectations } \\
\text { against the established or the } \\
\text { formation of counter-power. }\end{array}$ \\
\hline
\end{tabular}

Source: Weible and Sabatier 2017, own compilation. 
since policy programmes in PAF logic are connected to groups, these parallel programmes are competitive policy programmes and therefore not used by newly forming programmatic groups. It is however possible for an emerging programmatic group to take an existing policy programme as inspiration for the development of its own programme and only introduce some amendments that should help the programme's success. Some programmes might never pass the preparation phase (see programme $\mathrm{C}$ in Figure 1) because the programmatic groups are too weak; the policy programme does not fulfill the criteria of success (programme coherence, programme correlation to the national mood and response to emerging challenges), or the programmatic group has chosen the wrong point in time for an attempt to breakthrough - meaning they challenged the ruling group in their phase of dominance.

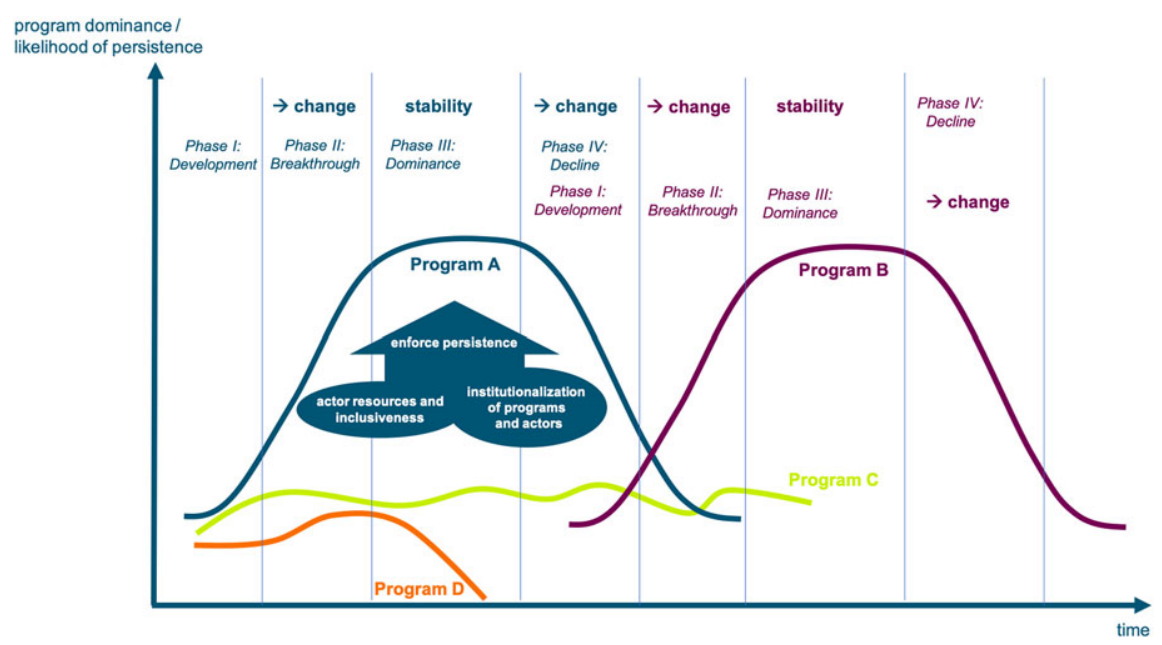

Figure 1. Policy programme cycles. Source: Own depiction of ideal types of phases that policy programmes run through (cyclical pattern), $X$ axis presents time (in years) and $Y$ axis presents the dominance of a programme that is connected to the likelihood of persistence.

Phase II: At a given point in time, a policy programme is likely to succeed and establish itself as the dominant policy programme in a given sector. This is particularly likely if either there is no current dominant policy programme so that the programmatic group only needs to prevail over programmatic groups at the same stage of development. Or, a policy programme may substitute a previously dominant policy programme. However, this is much more likely when the previously dominant programme has already entered the phase of decline and least likely when it is on the way to or at the top of its phase of dominance. In those cases, policy programme persistence and consequent stability are highest. If a policy programme breaks through, by definition, the actors who are connected to the programme come out on top, too.

Phase III: As a consequence of breakthrough, the programme gains popularity among those actors in the subsystem that feel they can equally profit from the dominant programme by engaging in it and thus gaining remaining posts in power. 
With a rising number of proponents of the programme, the programmatic group prospers and its power increases correspondingly. Top positions are occupied by the dominant programmatic group and the policy programme enjoys support among both officials and the public, who are climbing career ladders by joining the programmatic group and supporting the policy programme. This is the phase in which the policy programme and the programmatic group are strongest and hardest to tackle. While single policies of e.g. single-policy entrepreneurs have a chance to be adopted, provided that they fit the dominant policy programme, policy programmes that are different from the dominant policy programme almost necessarily fail as long as they do not present a group as strong and a programme as successful as the dominant one - which is almost impossible given that the dominant group already pervades the top positions. In this phase, there is programme stability, which does not mean that there are no new policies adopted, only that policy change occurs within the boundaries of the policy program's overall vision. Usually, the dominant programme is implemented step by step in this phase, meaning that one policy after another is adopted in the attempt to realize the entire policy programme over a long period of time and in every corner of a subsystem because adopting an encompassing policy reform that depicts all elements of the policy programme would be hard to realize and push through at once.

Phase IV: At one point in time, when the programmatic group's resources in terms of power positions and influence diminish, internal competition within the programmatic group over remaining resources arises. Resources diminish when the programmatic group's members leave office due to retirement or change in positions or are being replaced due to e.g. scandals or when the policy programme does not manage to adapt to emerging national challenges and present adequate measures to solve them. At this point, the policy programme and the associated programmatic group become less attractive to outsiders, as there is less to be compared to the alternative of turning to a new programmatic group with a new policy programme. Yet, the remaining individual actors in the policy subsystem equally strive towards increased authority in the sector and thus tend to orientate themselves to a different programmatic group with a different policy programme to be able to challenge the dominant one. The dominant programmatic group and the associated programme lose supporters and, with them, authority. In addition to that, while they had once represented innovation and change, they only represent stagnation at that point because the ideas and individuals have aged. Briefly speaking, once the policy programme and programmatic group in power have transcended the zenith of power, the likelihood increases that other programmatic groups and their policy programmes are successful. This leads to a new hypothesis to be added to the existing PAF:

Programme Cycle Hypothesis: A policy programme's persistence runs through a cyclical pattern, during which the likelihood of policy persistence depends on the phase in which the policy programme finds itself at a given point in time.

Figure 1 presents an ideal-typical illustration of the four phases of programme dominance (programme A) and the hypotheses. It visualizes how a policy programme (A) becomes successful, stays dominant for a certain amount of time and later 
declines. At the same time, it exemplifies the relation to other policy programmes: Parallel to policy programme dominance, there may be other policy programmes and programmatic actors striving to break through and become dominant. They will not succeed as long as the policy programme is at the peak of dominance because the power positions are occupied by the members of the dominant programmatic group, and other actors might have an interest in joining an emerging programme but not (yet) have the resources to make it succeed. An emerging programme, therefore, may only trigger the decline of a dominant programme if it manages to win over members of the other programmatic group, which is, in fact, only possible when the strong social identification of these programmatic actors with the policy programme is not damaged (e.g. by combining two policy programmes or providing a stronger social identification). The unsuccessful programmatic groups may either dissolve (programme D) or live on and wait for their time to come (programme C). After the programme cycle has ended, a new policy programme may take its place (programme B).

Drawing more explicitly on the theoretical overview presented in the preceding section and the foundations of the PAF, we can formulate hypotheses on the persistence of policy programmes and connected programmatic groups to account for policy stability. The hypotheses are best tested within a qualitative research design, preferably interviews, as shown in the later empirical case study. The degree of institutionalization of the programme and programmatic actors and the programmatic group's inclusiveness emerge as potentially enforcing factors for policy programme resilience both from existing literature and the insights from interviews that are later presented in the empirical case study. Path dependence displays as a further potential mechanism on stability, the power constellations of actors when institutions evolve (Thelen 2003; Beyer 2010). Thus, actors' institutionalization presents a determinant of stability because "an institution may persist even when most rational individuals prefer to change it, provided that a powerful elite that benefits from the existing arrangement has sufficient strength to resist its transformation" (Mahoney 2001). A powerful programmatic group and programmatic dominance are reinforced by the institutions that are created, because these institutions privilege the powerful programmatic group in distributing authority and, in turn, the powerful programmatic group again reinforces the institutions that present the pathdependent settings to support the policy programme by installing its members in the respective institutions (Mahoney 2001).

As with "a dominant political coalition successfully fending off all attempts by minorities to alter the political course" (Peters et al. 2005, 1278), a programmatic group similarly attempts to produce path dependencies that guarantee its dominance. Path dependence is ensured by establishing new institutions connected to the policy programme and by providing a discourse around the policy programme that is shared by as many policy actors and the public as possible. Thus, a high degree of institutionalization generates more of such positions at the top level and thus an increased number of supporters who secure the policy program's support. Furthermore, institutionalization becomes a process with its own dynamics, as newly created institutions strive towards their self-enhancement (Pierson 2002). This leads to the following hypothesis. 
Programme and Programmatic Actor Institutionalization Hypothesis: A policy programme is more likely to persist and persist over a longer period of time, the more institutions sustain its dominance through programmatic actors occupying these positions and the greater the authority these institutions and actor groups possess.

Especially in consensus democracies the homogeneity of programmatic actors can become a problem as successful programmatic groups need support from different political parties and different potential veto points (Tsebelis 2002; Zohlnhöfer 2009). Even if programmatic groups, whose members do not have a pluralistic background, gain power, they will not be able to implement their programme and, therefore, soon lose power. If the programmatic group exerts influence at many and various power positions in a sector, it can cushion changes in power relations that might lead to some actors being replaced as those newly elected take their place. As a consequence, a programmatic group - and the associated policy programme - are more likely to stay successful the broader and more various power positions it occupies, as the Actor Pluralism Hypothesis states.

Actor Pluralism Hypothesis: A policy programme is more likely to persist and persist over a longer period of time, the higher the variety and the wider the breadth of power positions that the individual members of the programmatic group occupy.

Despite the need for the breadth of power positions to be successful, a programmatic group continues to base on homogenous and commonly shared experiences of its programmatic actors. Among these are repeated instances of collaboration, in organizations, committees or similar types of bodies that are concerned with intellectual thinking and decision-making. Only then it is possible for them to develop a feeling of belonging, positive evaluation, and emotional attachment to what emerges as a social group of actors that can later turn into a programmatic group when committing to a jointly shared and supported policy programme. The policy programme thereby can be based on their previous work, which normally resembles their way of thinking and preferences. Nevertheless, these preferences are supposed to be much less stable than it is the case with the ACF and core beliefs or perspectives of rationality that presume stable and certain preferences but much more pronounced than in ambiguous environments that form the basis of the MSF. More important for success is the extent to which individual members of social groups exhibit group loyalty. A higher degree of group loyalty and strong identification of members at the various power positions ensures long-term support of the group throughout the policy process, but a strong identification regarding e.g. political parties easily leads to strong polarization (Iyengar and Westwood 2015), which leaves programmatic groups with the challenge of decreasing potential polarization while keeping group loyalty and identification high. Therefore, the inclusion of leading figures of the party competition in democracies can have a negative impact as these polarizing people prevent actors from joining the group. Consequently, programmatic success is more likely when the programmatic group manages to be inclusive, without putting prominent, polarizing figures centrestage in group representation. 
Actor Inclusiveness Hypothesis: A policy programme is more likely to persist and persist over a longer period of time if the programmatic group attached to it is not primarily associated with prominent figures of partisan competition.

\section{Empirical illustration from German health policy: Competition in a Solidaristic Framework}

To illustrate the empirical relevance of the theoretical argument presented in this article, this section takes German health policy as an example. The selection of this case is made considering the case as a deviant one with regard to existing theoretical approaches and thereby checking an alternative explanation for the outcome (policy change) (Seawright and Gerring 2007, 297). Regarding the validity of the findings that support the formulated theoretical claims, the case study rests on the assumption of process tracing that the evidence supporting the theoretical explanation is most trusted when alternative explanations fall short in explaining the process (Bennett and Elman 2006, 460). Further cross-case studies then are to confirm the explanatory power of PAF. German health policy fulfills both the criteria of being largely independent of changes in government, with a strong selfgovernance and a range of decision-makers not reshuffled through elections, and of a sector close to the state, with the statutory health insurance (SHI), state oversight on hospitals and the self-governance as a mediate public administration, among other characteristics. Furthermore, German health policy is a sector that must repeatedly deal with emerging challenges, complex actor constellations and different policy ideas that fight over getting a hearing. German health policy is an exciting case study for observing the relation between innovative programmatic groups and programmatic gridlock. Previous literature indicates a paradox at this point. On the one side, analyses depict substantial changes through a programmatic elite that encouraged a systematic restructuring of the health system in the last quarter-century (Knieps 2015; Busse et al. 2017; Hornung and Bandelow 2018). On the other side, there is the observation that fundamental reforms were not realized, although a broad political majority supports them. How can we explain this apparent contradiction between reform realization and blockades, with an ongoing realization of specifically directed reforms? The established perspectives of policy research do not provide an adequate answer to this question, as neither systematic policy core beliefs of a dominant coalition nor single political entrepreneurs or situational aspects nor persuading narratives or systematic interests of corporative actors explain the two sides of reform success and failure. The empirical illustration of programme conjunctures presented here for German health policy, in fact, shows the change in strategies of an identifiable programmatic group towards specific policies, dependent on the direct relation of the programmatic group to its own policy programme. The empirical data supporting this argument were gathered during research projects on German health policy and stemmed from repeated interviews with high-ranking officials and actors in key positions as well as outsiders. In sum, the data include some 20 of those in-depth interviews. 


\section{Phase I: Enquete Commission}

German health policy had experienced fundamental blockades of structural reform that resulted from the institutional conditions of the German consensus democracy (Lijphart 2012) and the contradictory substantial policy goals of the involved actors. The evolution of the first programmatic group in German health policy at the end of the 1980s presented a precondition for surmounting these blockades and for realizing in several steps a reform programme called "Competition in a Solidaristic Framework" (Knieps 2017). This programmatic group comprised actors from different areas of the state (government, parliament, self-governance, sickness fund associations) and different parties, all of them having divergent ideological orientations. The origins of both the programmatic group and the policy programme can be traced back to the Enquete Commission "Structural Reform of the Statutory Health Insurance" from 1987 to 1990. The final report of this Commission already included a number of reform proposals that were adopted during the subsequent 20 years, and the members of the Commission achieved central power positions in establishing this programme. Interviews with these actors have confirmed that many ideas from this Commission were later translated into policy and that the actors mutually helped each other to enter higher policy positions in administration and self-governance.

\section{Phase II: a cross-partisan compromise and the German Health Care Structure Act 1992}

The breakthrough phase found expression in the preparation of the first structural reform on the basis of the policy programme from 1990 to 1992. In these years, the programmatic actors that were bound by their biographical intersection of the Enquete Commission attracted other programmatic actors that joined the group and were equally biographically bound to existing members of the group. While the core of this group consisted primarily of bureaucrats that occupied central positions in the health ministry, such as heads of divisions and departments (e.g. Franz Knieps, Manfred Lang, Ulrich Tilly), the group also encompassed central figures of the self-governance (like Wolfgang Kaesbach, Christopher Herrmann) (actor pluralism). With these varieties of resources coming from central positions in the health sectors without being subject to partisan competition (programmatic actors partly had partisan affiliations, which however did not play a central role, as one interview partner emphasizes), the programmatic group was able to realize the adoption of its first step in the policy programme: the Health Care Structure Act 1992. At this point, the partisan competition only became relevant in the sense that the programmatic group needed to get the partisan decision-makers of government on board. For this undertaking, it was necessary that the programme provided a vision that multiple political camps could likewise identify with. The Lahnstein compromise - named according to the place where the reform was negotiated between party representatives and programmatic actors - finally resulted in the reform proposal that was later approved by the parliament, thanks to the preparation of the programmatic actors in cooperation with the governing majority. The strategic alliances formed with multiple actors in key positions thereby enabled 
to pass the reform, also because the content was not considered as a "pet policy" of outstanding figures of partisan competition (actor inclusiveness).

\section{Phase III: competition in a Solidaristic Framework from 1992 to 2011}

The phase of stability finally ranged from 1992 to 2011 . In this period, several also major policy reforms were adopted that are in line with the overall vision of the policy programme "Competition in a Solidaristic Framework." Consequently, the policies introduced elements of competition in the health care sector, starting from the competition between sickness funds that were enhanced by the Health Care Structure Act 1992 and proceeding with the Statutory Health Insurance (SHI) Modernization Act 2003 that further strengthened this competition e.g. by selective contracts with ambulatory health care suppliers and implemented the Joint Federal Committee (JFC) as the central body of decision-making. The 2007 reform was even labelled the Act to Enhance Competition in the Statutory Health Insurance (SHI) and also established a new institution, the health care fund, that since then has occupied the important role of collecting wage-related contributions of all insured citizens independent of the sickness funds and then reallocates these funds to the sickness funds by also complying with a risk compensation scheme. This has also led to the creation of new jobs, for example, in the now Federal Agency for Social Security (Bundesamt für Soziale Sicherung, BAS). Connected to the vision of competition, there is an increasing amount of scientific reports on the arrangement, procedure and effects of competition in the health care system. As a result, many scientific advisors that belong to the programmatic group since its beginnings now profit from the programme in the sense that they cover advisory positions close to the state with significant influence in the policy process, where they continuously spread the idea of competition (programme and actor institutionalization). The final reform that finalized the vision of increased competition in the health care sector was the Pharmaceutical Market Restructuring Act (Arzneimittelmarktneuordnungsgesetz, AMNOG). It made an additional benefit assessment for the introduction of new medical products into the market obligatory and only then allowed the companies to enter price negotiations. If no additional benefit can be documented, the product is automatically priced according to the reference pricing system. This again led to new jobs and the creation of the Institute for Quality and Efficiency in Health Care (Institut für Qualität und Wirtschaftlichkeit im Gesundheitswesen, IQWIG) (programme and actor institutionalization).

Although the programmatic group once started as a great reformer to effect substantial changes in the health system, it fended off other reform proposals in this phase. For instance, a group concerned with managed care, which picked up on the problem of a strong separation between the sectors of inpatient and outpatient care, was formed and tried to gain influence in the system. Some elements of managed care were indeed compatible with the programme of the dominant programmatic group. Hence, these were partly integrated into the policy programme, such as medical service centres, which were originally called polyclinics, later health centres and finally found the narrative of medical service centres that fit into the programme. Managed care as a fixed term was not usable as a narrative, and the group and programme did not make it to the breakthrough phase because of the lack of 
power resources, despite selected elements being adopted and despite several members of the dominant programmatic group being, in fact, favourable towards essential parts of managed care and having sympathy for them. A second substantial initiative to reorganize the health system targeted the programme of the so-called "citizen insurance." Again, a majority of members of the dominant programmatic group supported the concept as to content. Apart from the dominant programmatic group, the programme attracted support among the public and - recently in the course of the interest crisis - generated consent among private health insurances due to the increasing external problem pressure. Yet, the main proponent of the programme of citizen insurance was and still is in deep personal conflict with the leading figures of the dominant programmatic group. At the top of the group of advocates behind a citizen insurance are strongly polarizing partisan politicians who so far did not manage to form a programmatic group holding resources and being powerful. Furthermore, the Greens and the Social Democrats alternately employed the concept in several electoral campaigns, which makes it almost impossible to form a party-spanning group of supporters. Programmatic groups do not function in their logic if they only involve members of specific parties and if their programme is in fact a partisan programme. As a consequence, and in spite of relatively broad support, the programme did not reach the phase of breakthrough because it is too attached to prominent partisan actors (actor inclusiveness).

\section{Phase IV: Reactionary policy-making in economic prosperity}

Since the last major policy reform of 2011, the policy programme and the programmatic group have been declining. Reasons for this decline are numerous, but the most important ones are that leading representatives of the group have reached retirement age, that the group increasingly experienced internal conflict because of tangible decisions, and that there is a partial disillusionment regarding the substantial results of the reform programme. In light of the current decline of the programme, new programmatic groups have the chance to occupy central positions. If key positions are replaced with actors that are part of a social group that emerged out of the usual bodies of cooperation, such actors may emerge as a new programmatic group. A recent example of strong and close cooperation on a central topic in German health care is that of care policy. Within a concerted action on care policy, a group of actors from state, unions, associations and self-governance repeatedly met to work out reform proposals that are now considered for future reforms in this policy area. The lead actor in writing the reform programme has been promoted within the ministry and now occupies a central post in the policy formulation process (source for this information is an interview in the ministry). A smaller programmatic group has already taken its chance to realize its programme of strengthening and valorising nursing professions in several smaller reform steps. The recent Covid-19 pandemic puts the issue of care policy on the agenda but sheds light on a formerly neglected group of actors committing themselves to a programme on public health in connection with scientific advice, as it has been the case in the UK (Ettelt and Hawkins 2018). Here, we see much leeway for the establishment of (a) further, encompassing programmatic group(s). Other initiatives coexist, for instance, with respect to the digitalization of the German health system or 
patient-oriented goal governance - but none of these groups and programmes have reached the breakthrough phase so far, nor is it clear that they have already formed as a programmatic group (see Figure 2).

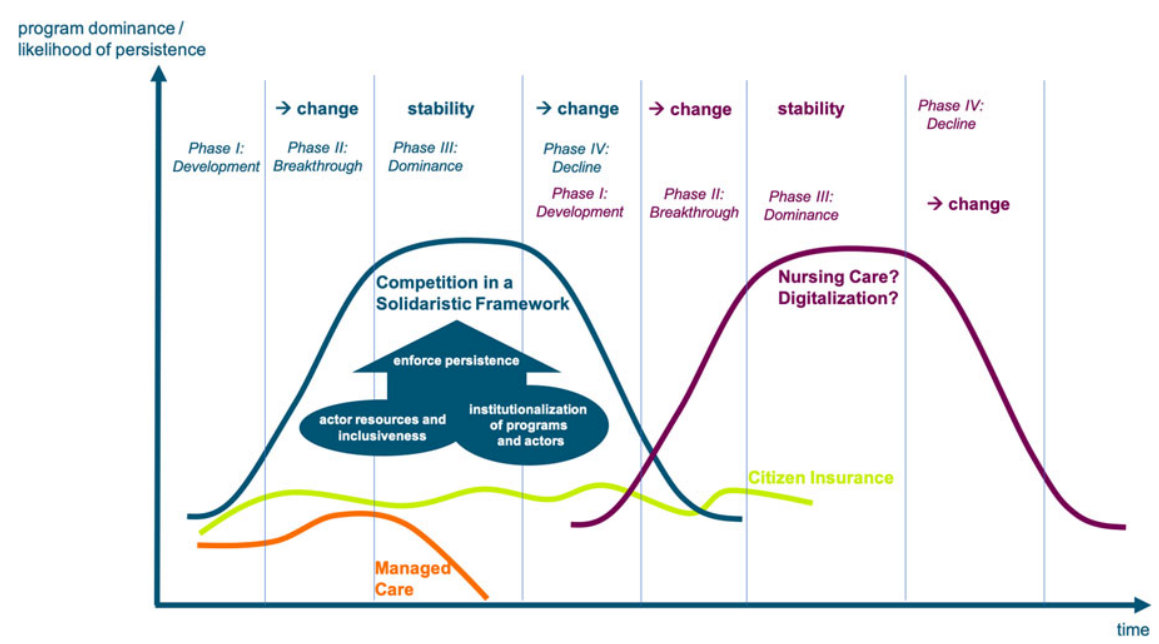

Figure 2. Empirical illustration of the case study according to theoretical considerations. Source: Own depiction based on interviews with programmatic actors that have promoted or still promote these programmes (at least one interviewee per programme).

\section{Conclusion}

This contribution presents insights into policy processes and avenues for future research in several respects. Firstly, the PAF constitutes an additional theoretical lens to capture policy process dynamics, especially how the dominance of groups and their programmes persists and how it eventually ends. Informed by the empirical case and existing literature, its main argument is that the institutionalization of policy programmes and their programmatic actors, as well as the inclusiveness and pluralism of programmatic groups, affects policy programme persistence. With a view on programmatic groups and policy programmes as irrevocably tied, the PAF also explains strategies that are not covered by all established theories of the policy process but nonetheless quite ancient knowledge: The reformers of today become the conservatives of tomorrow.

Secondly, while there is evidence that PAF's theoretical claims sometimes hold true in explaining policy processes, one must acknowledge that this is not always the case. There are important limitations and scope conditions that constrain the formation of programmatic groups and policy programs' success. First of all, while all political systems entail opportunities for networking and thereby present the basis for contact and joint development of ideas between policy actors who later may cooperate based on their biography, these chances are not equally distributed across political systems. Given that the programmatic approach roots in French political science, the École Nationale d'Administration (ENA), which every individual who becomes a powerful policy actor has typically run through, presents the place to be when 
programmatic actors are born. In the analysed case, the programmatic group and its policy programme were initiated in the Enquete Commission, but this is a nonregular body of cooperation. Policy programmes and programmatic actors, therefore, need commissions where they can begin cooperation, think, and develop ideas to mould the sectoral policy of a state over a longer period of time.

Thirdly, and relatedly, there are and will be situations in which no programmatic group or policy programme exists. This is currently the case in German health policy, after the period of programmatic dominance, because reforms largely respond to upcoming problems with a generous expense policy instead of tackling structural problems. Here, PAF does not provide the theoretical means to explain these developments while other theories do. Therefore, it is important to note that PAF can provide an added value in some cases but not in others. Similarly, the idea of policy programmes following cyclical patterns is sometimes visible and sometimes not. Yet, there are instances in which the link between programmatic groups and policy programmes is connected to the rise and decline of political careers, and this is when PAF unfolds its explanatory potential.

Acknowledgements. None.

Funding sources. This work was funded by the DFG grant number DFG BA 1912/3-1 and the ANR grant number ANR-17-FRAL-0008-01.

Data availability statement. This study does not employ statistical methods and no replication materials are available.

\section{References}

Bandelow NC, Hornung J and Smyrl ME (2020) Theoretical Foundations of the Programmatic Action Framework (PAF). European Policy Analysis (early view). doi: 10.1002/epa2.1083.

Bandelow NC and Hornung J (2019) One Discourse to Rule Them All? Narrating the Agenda for Labor Market Policies in France and Germany. Policy and Society, 38(3): 408-428. doi: 10.1080/14494035.2019. 1641379.

Bauer MW and Knill C (2014) A Conceptual Framework for the Comparative Analysis of Policy Change: Measurement, Explanation and Strategies of Policy Dismantling. Journal of Comparative Policy Analysis: Research and Practice, 16(1): 28-44. doi: 10.1080/13876988.2014.885186.

Baumgartner FR, Breunig C, Green-Pedersen C, Jones BD, Mortensen PB, Nuytemans M and Walgrave S (2009) Punctuated Equilibrium in Comparative Perspective. American Journal of Political Science, 53(3): 603-620. doi: 10.1111/j.1540-5907.2009.00389.x.

Baumgartner FR, Jones BD and Mortensen PB (2017) Punctuated Equilibrium Theory: Explaining Stability and Change in Public Policymaking. In Weible CM and Sabatier PA (eds.), Theories of the Policy Process. Boulder, CO: Westview Press, 55-102.

Béland D (2010) Reconsidering Policy Feedback: How Policies Affect Politics. Administration \& Society, 42(5): 568-590. doi: 10.1177/0095399710377444.

Béland D and Howlett M (2016) The Role and Impact of the Multiple-Streams Approach in Comparative Policy Analysis. Journal of Comparative Policy Analysis: Research and Practice, 18(3): 221-227. doi: 10.1080/13876988.2016.1174410.

Béland D and Schlager E (2019) Varieties of Policy Feedback Research: Looking Backward, Moving Forward. Policy Studies Journal, 47(2): 184-205. doi: 10.1111/psj.12340.

Bennett A and Elman C (2006) Qualitiative Research: Recent Developments in Case Study Methods. Annual Review of Political Science, 9(1): 455-476. doi: 10.1146/annurev.polisci.8.082103.104918.

Beyer J (2010) The Same or Not the Same - On the Variety of Mechanisms of Path Dependence. International Journal of Social Sciences, 5(1): 1-11. 
Busse R, Blümel M, Knieps F and Bärnighausen T (2017) Statutory Health Insurance in Germany: A Health System Shaped by 135 Years of Solidarity, Self-Governance, and Competition. The Lancet, 390(197): 31280-31281. doi: 10.1016/s0140-6736.

Calanni JC, Siddiki SN, Weible CM and Leach WD (2014) Explaining Coordination in Collaborative Partnerships and Clarifying the Scope of the Belief Homophily Hypothesis. Journal of Public Administration Research and Theory, 25(3): 901-927. doi: 10.1093/jopart/mut080.

Capano G and Howlett M (2009) Introduction: The Multidimensional World of Policy Dynamics. In Capano G and Howlett M (eds.), European and North American Policy Change. Drivers and Dynamics, New York, USA: Routledge, 1-12.

Capano G and Howlett M (2019) Causal Logics and Mechanisms in Policy Design: How and Why Adopting a Mechanistic Perspective Can Improve Policy Design. Public Policy and Administration. doi: $10.1177 / 0952076719827068$.

Coleman WD, Skogstad GD and Atkinson MM (1996) Paradigm Shifts and Policy Networks: Cumulative Change in Agriculture. Journal of Public Policy, 16(3): 273-301. doi: 10.1017/S0143814X00007777.

deLeon P (2007) Afterward: The Once and Future State of Policy Termination. International Journal of Public Administration, 20(12): 2195-2212. doi: 10.1080/01900699708525292.

Döhler M (1991) Policy Networks, Opportunity Structures and Neo-Conservative Reform Strategies in Health Policy. In Marin B and Mayntz R (eds.), Policy Networks: Empirical Evidence and Theoretical Considerations. Frankfurt am Main: Campus Verlag, 235-296.

Dolan J. 2000. Influencing Policy at the Top of the Federal Bureaucracy: A Comparison of Career and Political Senior Executives. Public Administration Review, 60(6): 573-581. doi: 10.1111/0033-3352.00119.

Doosje B, Spears R and Ellemers N (2010) Social Identity as Both Cause and Effect: The Development of Group Identification in Response to Anticipated and Actual Changes in the Intergroup Status Hierarchy. British Journal of Social Psychology, 41(1): 57-76. doi: 10.1348/014466602165054.

Dunlop CA (2009) Policy Transfer as Learning: Capturing Variation in What Decision-Makers Learn from Epistemic Communities. Policy Studies, 30(3): 289-311. doi: 10.1080/01442870902863869.

Elander I and Gustavsson E (2019) From Policy Community to Issue Networks: Implementing Social Sustainability in a Swedish Urban Development Programme. Environment and Planning C: Politics and Space, 37(6): 1082-1101. doi: 10.1177/2399654418820077.

Ettelt S and Hawkins B (2018) Scientific Controversy, Issue Salience, and E-Cigarette Regulation: A Comparative Study of Policy Debates in Germany and England. European Policy Analysis. 4(2): 255-274. doi: 10.1002/epa2.1039.

Faure S (2020) Defeating the Austerians of the Warfare State. French Arms Policy Through the Lens of the Programmatic Action Framework. European Policy Analysis. doi: 10.1002/epa2.1081.

Fischer M, Ingold K, Sciarini P and Varone F (2016) Dealing With Bad Guys: Actor- and Process-level Determinants of the "Devil Shift" in Policy Making. Journal of Public Policy, 36(2): 309-334. doi: 10.1017/ S0143814X15000021.

Genieys W (2010) The New Custodians of the State: Programmatic Elites in French Society. New Brunswick, NJ: Transaction Publishers.

Genieys W and Hassenteufel P (2015) The Shaping of New State Elites: Healthcare Policymaking in France Since 1981. Comparative Politics, 47(3): 280-295. doi: 10.5129/001041515814709301

Genieys W and Smyrl M (2008) Inside the Autonomous State: Programmatic Elites in the Reform of French Health Policy. Governance, 21(1): 75-93. doi: 10.1111/j.1468-0491.2007.00386.x.

Haas PM (1992) Introduction: Epistemic Communities and International Policy Coordination. International Organization, 46(1): 1-35.

Hacker JS and Pierson P (2014) After the "Master Theory": Downs, Schattschneider, and the Rebirth of Policy-Focused Analysis. Perspectives on Politics, 12(3): 643-662. doi: 10.1017/S1537592714001637.

Hall PA (1993) Policy Paradigms, Social Learning, and the State: The Case of Economic Policymaking in Britain. Comparative Politics, 25(3): 275-296. doi: 10.2307/422246.

Hassenteufel P and Genieys W (2020) The Programmatic Action Framework: An Empirical Assessment. European Policy Analysis (Forthcoming). doi: 10.1002/epa2.1088.

Hassenteufel P, Smyrl M, Genieys W and Moreno-Fuentes FJ (2010) Programmatic Actors and the Transformation of European Health Care States. Journal of Health Politics, Policy and Law, 35(4): 517-538. doi: 10.1215/03616878-2010-015. 
Herweg N, Huß C and Zohlnhöfer R (2015) Straightening the Three Streams: Theorizing Extensions of the Multiple Streams Framework. European Journal of Political Research, 54(3): 435-449. doi: 10.1111/14756765.12089.

Herweg N, Zahariadis N and Zohlnhöfer R (2017) The Multiple Streams Framework: Foundations, Refinements, and Empirical Applications. In Weible CM and Sabatier PA (eds.), Theories of the Policy Process. Boulder, CO: Westview Press, 17-53.

Hogan J (2019) The Critical Juncture Concept's Evolving Capacity to Explain Policy Change. European Policy Analysis, 5(2): 170-189. doi: 10.1002/epa2.1057.

Hogg MA, Dominic A and Brewer MB (2017) Social Identity: The Role of Self in Group Processes and Intergroup Relations. Group Processes \& Intergroup Relations, 20(5): 570-581. doi: 10.1177/136843 0217690909.

Hornung J and Bandelow NC (2018) The Programmatic Elite in German Health Policy: Collective Action and Sectoral History. Public Policy and Administration. doi: 10.1177/0952076718798887.

Hornung J, Bandelow NC and Vogeler CS (2019) Social Identities in the Policy Process. Policy Sciences, 52(2): 211-231. doi: 10.1007/s11077-018-9340-6.

Howlett M, Kim J and Weaver P (2006) Assessing Instrument Mixes through Program- and Agency-Level Data: Methodological Issues in Contemporary Implementation Research. Review of Policy Research, 23(1): 129-151. doi: 10.1111/j.1541-1338.2006.00189.x.

Howlett M, Mukherjee I and Koppenjan J (2017) Policy Learning and Policy Networks in Theory and Practice: The Role of Policy Brokers in the Indonesian Biodiesel Policy Network. Policy and Society, 36(2): 233-250. doi: 10.1080/14494035.2017.1321230.

Iyengar S and Westwood SJ (2015) Fear and Loathing across Party Lines: New Evidence on Group Polarization. American Journal of Political Science, 59(3): 690-707. doi: 10.1111/ajps.12152.

Jetten J, Branscombe NR, Spears R and McKimmie BM (2003) Predicting the Paths of Peripherals: The Interaction of Identification and Future Possibilities. Personality and Social Psychology Bulletin, 29(1): 130-140. doi: 10.1177/0146167202238378.

Jochim AE and May PJ (2010) Beyond Subsystems: Policy Regimes and Governance. Policy Studies Journal, 38(2): 303-327. doi: 10.1111/j.1541-0072.2010.00363.x.

Jordan A, Bauer MW and Green-Pedersen C (2013) Policy Dismantling. Journal of European Public Policy, 20(5): 795-805. doi: 10.1080/13501763.2013.771092.

Jordan G and Schubert K (1992) A Preliminary Ordering of Policy Network Labels. European Journal of Political Research, 21(1-2): 7-27. doi: 10.1111/j.1475-6765.1992.tb00286.x.

Kern F, Kuzemko C and Mitchell C (2014) Measuring and Explaining Policy Paradigm Change: the Case of UK Energy Policy. Policy \& Politics, 42(4): 513-530. doi: 10.1332/030557312x655765.

Kingdon JW (2003) Agendas, Alternatives, and Public Policies, 2nd ed. Boston, MA: Pearson Education.

Knieps F (2015) Neue Versorgungsformen: Sachstand nach dem GKV-Versorgungsstärkungsgesetz. Gesundheits- und Sozialpolitik, 69(6): 7-15. doi: 10.5771/1611-5821-2015-6-7.

Koning EA (2016) The Three Institutionalisms and Institutional Dynamics: Understanding Endogenous and Exogenous Change. Journal of Public Policy, 36(4): 639-664. doi: 10.1017/S0143814X15000240.

Lijphart A (2012) Patterns of Democracy. Government Formes and Performance in Thirty-Six Countries. New Haven \& London: Yale University Press.

Mahoney J (2001) Path-Dependent Explanations of Regime Change: Central America in Comparative Perspective. Studies in Comparative International Development, 36(1): 111-141. doi: 10.1007/BF026 87587.

Marsh D and Rhodes RAW (1992) Policy Communities and Issue Networks. In David M and Rhodes RAW (eds.), Policy Networks in British Government. Oxford: Oxford University Press, 249-287.

Matti S and Sandström A (2011) The Rationale Determining Advocacy Coalitions: Examining Coordination Networks and Corresponding Beliefs. Policy Studies Journal, 39(3): 385-410. doi: 10.1111/ j.1541-0072.2011.00414.x.

Mavrot C and Sager F (2018) Vertical Epistemic Communities in Multilevel Governance. Policy \& Politics, 46(3): 391-407. doi: 10.1332/030557316X14788733118252.

May PJ and Jochim AE (2013) Policy Regime Perspectives: Policies, Politics, and Governing. Policy Studies Journal, 41(3): 426-452. doi: 10.1111/psj.12024. 
Mettler S and Sorelle M (2017) Policy feedback theory. In Weible CM and Sabatier PA (eds.), Theories of the Policy Process. Boulder, CO: Westview Press, 103-134.

Mintrom M and Norman P (2009) Policy Entrepreneurship and Policy Change. Policy Studies Journal, 37(4): 649-667. doi: 10.1111/j.1541-0072.2009.00329.x.

Nyby J, Nygård M and Blum S (2018) Radical Reform or Piecemeal Adjustments? The Case of Finnish Family Policy Reforms. European Policy Analysis, 4(2): 190-213. doi: 10.1002/epa2.1050.

Oliver MJ and Pemberton H (2004) Learning and Change in 20th-Century British Economic Policy. Governance, 17(3): 415-441. doi: 10.1111/j.0952-1895.2004.00252.x.

Peters BG, Pierre J and King DS (2005) The Politics of Path Dependency: Political Conflict in Historical Institutionalism. The Journal of Politics, 67(4): 1275-1300. doi: 10.1111/j.1468-2508.2005.00360.x.

Pierson P (2002) The Limits of Design: Explaining Institutional Origins and Change. Governance, 13(4): 475-499. doi: 10.1111/0952-1895.00142.

Pollex J and Lenschow A (2019) Many Faces of Dismantling: Hiding Policy Change in Non-legislative Acts in EU Environmental Policy. Journal of European Public Policy: 1-21. doi: 10.1080/13501763.2019. 1574869.

Rinscheid A, Eberlein B, Emmenegger P and Schneider V (2019) Why Do Junctures Become Critical? Political Discourse, Agency, and Joint Belief Shifts in Comparative Perspective. Regulation \& Governance. doi: 10.1111/rego.12238.

Sabatier PA and Jenkins-Smith HC (eds.) (1993) Policy Change and Learning: An Advocacy Coalition Approach, Theoretical Lenses on Public Policy. Boulder, CO: Westview Press.

Sager F and Thomann E (2017) Multiple Streams in Member State Implementation: Politics, Problem Construction and Policy Paths in Swiss Asylum Policy. Journal of Public Policy, 37(3): 287-314. doi: 10.1017/S0143814X1600009X.

Seawright J and Gerring J (2008) Case Selection Techniques in Case Study Research: A Menu of Qualitative and QuantitativeOptions. Political Research Quarterly, 61(2): 294-308. doi: 10.1177/106591 2907313077.

Steinmo S and Watts J (1995) It's the Institutions, Stupid!: Why Comprehensive National Health Insurance Always Fails in America. Journal of Health Politics, Policy and Law, 20(2): 329-372. doi: 10.1215/ 03616878-20-2-329.

Stern MJ and Coleman KJ (2015) The Multidimensionality of Trust: Applications in Collaborative Natural Resource Management. Society \& Natural Resources, 28(2): 117-132. doi: 10.1080/08941920.2014. 945062.

Tanis M and Postmes T (2005) A Social Identity Approach to Trust: Interpersonal Perception, Group Membership and Trusting Behaviour. European Journal of Social Psychology, 35(3): 413-424. doi: 10.1002/ejsp.256.

Thelen KA (2003) How Institutions Evolve. In Rueschemeyer D and Mahoney J (eds.), Cambridge Studies in Comparative Politics, Cambridge: Cambridge University Press, 208-240.

Tsebelis G (2002) Veto Players: How Political Institutions Work. Princeton: Princeton University Press.

Weible CM, Heikkila T and Pierce J (2018) Understanding Rationales for Collaboration in High-Intensity Policy Conflicts. Journal of Public Policy, 38(1): 1-25. doi: 10.1017/S0143814X16000301.

Weible CM and Ingold K (2018) Why Advocacy Coalitions Matter and Practical Insights About Them. Policy \& Politics, 46(2): 325-343. doi: 10.1332/030557318x15230061739399.

Weible CM and Sabatier PA (eds.) (2017) Theories of the Policy Process. 4th ed. Boulder, CO: Westview Press.

Wilsford D (1994) Path Dependency, or Why History Makes it Difficult but not Impossible to Reform Health Care Systems in a Big Way. Journal of Public Policy, 14(3): 251-283. doi: 10.1017/S01438 $14 \mathrm{X} 00007285$.

Wilson CA (2000) Policy Regimes and Policy Change. Journal of Public Policy, 20(3): 247-274. doi: 10.1017/ S0143814X00000842.

Zafonte M and Sabatier PA (1998) Shared Beliefs and Imposed Interdependencies as Determinants of Ally Networks in Overlapping Subsystems. Journal of Theoretical Politics, 10(4): 473-505. doi: 10.1177/ 0951692898010004005 . 
Zahariadis N (2007) The Multiple Streams Framework: Structure, Limitations, Prospects. In Sabatier PA (ed.), Theories of the Policy Process, Boulder, CO: Westview Press, 65-92.

Zahariadis N (2014) Ambiguity and Multiple Streams. In Sabatier PA and Weible CM (eds.) Theories of the Policy Process, Boulder, CO: Westview Press, 25-58.

Zapp M and Powell JJW (2016) How to Construct an Organizational Field: Empirical Educational Research in Germany, 1995-2015. European Educational Research Journal, 15(5): 537-557. doi: $10.1177 /$ 1474904116641422.

Zohlnhöfer R (2009) How Politics Matter When Policies Change: Understanding Policy Change as a Political Problem. Journal of Comparative Policy Analysis: Research and Practice, 11(1), 97-115. doi: $10.1080 / 13876980802648300$.

Cite this article: Bandelow NC and Hornung J (2021). Policy programme cycles through old and new programmatic groups. Journal of Public Policy 41, 633-652. https://doi.org/10.1017/S0143814X20000185 